\title{
INFLUENCE OF SCHOOL LOCATION ON COST EFFICIENCY IN PUBLIC SECONDARY SCHOOLS IN BOMET COUNTY, KENYA
}

\author{
Philip Kimutai arap Kirui ${ }^{1}$, \\ David Kuria Wamukuru², \\ Fedha Flora ${ }^{3}$ \\ ${ }^{1}$ Doctor of Philosophy Student, \\ Department of Curriculum, Instruction \\ and Educational Management, \\ Egerton University, \\ Kenya \\ 2,35enior Lecturer, \\ Department of Curriculum, Instruction \\ and Educational Management, \\ Egerton University, \\ Kenya
}

\begin{abstract}
:
Kenyan public secondary schools are intended to run at cost that is both cheap and sustainable. Despite this, the cost of education in most public secondary schools in Bomet County is still high in relative terms. This could indicate that public schools are operating inefficiently in terms of costs. The purpose of this study was to investigate the influence of school location on cost efficiency in public secondary schools in Bomet County, Kenya. The target population of the study was two hundred and seventy principals of public secondary schools and all the five Sub-County Directors of Education in Bomet County. Using stratified and simple random sampling approaches, a sample of 175 principals was chosen. The data was collected from the principals using a semi-structured questionnaire, and the data from the Sub-county Directors of Education was collected using an interview schedule. The data was collected from the principals using a semi-structured questionnaire, and the data from the Sub-county Directors of Education was collected using an interview schedule. The Content Validity Index was used to check for validity, and it found that all variables had an S-CVI of greater than 0.9 , indicating that they were all valid and could be used in the study. All variables had Cronbach alpha coefficients of greater than 0.7 , indicating that the variables were internally reliable enough to be used in the study. The data was analyzed and summarized using descriptive statistics, such as frequencies, means, and standard deviations. To test the hypotheses, the researchers employed simple linear regression analysis in inferential statistics to see how well school location could predict cost efficiency. Statistical operations on data analysis were
\end{abstract}

\footnotetext{
${ }^{1}$ Correspondence email: kiruibilly@gmail.com
} 
performed using the Statistical Packages for Social Sciences (SPSS) statistics software. The influence of the school location on the cost efficiency in public secondary schools was examined using nine indicators. These indicators included the effects of school location on diverse expenses such as water services provision, electricity services provision, food supplies, administration cost, extracurricular activities, access to workshops and seminars, external support services, transportation costs, and missing on the cost-saving opportunities. The study results indicated that the respondents indicated that the school incurred huge expenses on water bills, and food supplies to a very small extent. The study also concluded on the presence of a statistically significant influence of school location on the cost efficiency of public secondary schools in Bomet County. These results were attributed to higher operational costs associated with their geographical remoteness and sparsely populated schools, which were then not able to benefit from economies of scale in their operations.

Keywords: cost efficiency, public secondary schools, school location

\section{Introduction}

Diverse studies on school location have noted variations in the cost efficiency of schools located in rural and urban schools as a consequence of input and output variables in secondary school education. A few studies have focused on students' academic measures as an output variable linkable to cost efficiency in education (Ferraro et al., 2021; Agasisti et al., 2016; Gralka et al., 2019; Barra et al., 2018). On the other hand, cost efficiency can be measured in rural and urban schools using input resources, proxied by variables including, teacher-student ratio, other school personnel-student ratio, school expenditure per student, and the average socio-economic status of students (Xie \& Zhang, 2019). The authors are in consensus that for all macro-economic areas, some organizational variables and some context variables affect school efficiency. The input and output measures may suggest that different strategies are necessary to support efficiency improvements in rural and urban schools.

Studies show that public secondary schools in Bomet County like several schools around the country experience cost inefficiency in the manner in which educational resources are utilized (Koriyow, 2017; Chepkwony et al., 2020; Kosgei et al., 2018; Chirchir et al., 2019; Kitur et al., 2020). For instance, records held by the county education office in Bomet indicate that there is cost inefficiency in the utilization of educational resources in public secondary schools (Ministry of Education, 2018). The variance between the average expected unit costs and the actual incurred in the county between the year 2014 and 2017 depicts cost inefficiency. Efficiency variance refers to the difference between the theoretical amount of inputs required to produce a unit of output and the actual number of inputs used to produce the unit of output (Flores, 2017). The difference between expected required inputs and actual required inputs can be due to inefficiencies in labour or use of resources, or errors in the assumptions used to set input expectations (Hanushek 
\& Woessmann, 2012). These differences are indication of cost inefficiency due to high cost of providing education. Inefficiencies in public secondary schools take education to a breaking point by facilitating loss of scarce resources through wastages and increased costs. School management need to embrace prudent utilization of these scarce resources for the realization of the desired educational objectives at reduced costs.

Efficiency variance analyzes the effectiveness with respect to staff, educational materials, machine time and other production factors. Efficiency variance is the difference between the theoretical amount of inputs required to produce a unit of output and the actual number of inputs used to produce the unit of output (Messer, 2016). The expected inputs to produce the unit of output mimic models or experience. The difference between expected required inputs can be due to inefficiencies in labour or use of resources, or errors in the assumptions used to set input expectations. In education, efficiency variance analyses the effectiveness with respect to labour, materials, machine time and other production factors. Table 1 shows the average education unit costs for the years 20142017 in Bomet County.

Table 1: The Average Unit Costs for the Years 2016-2019 in Kenya shillings

\begin{tabular}{|l|c|c|c|c|}
\hline $\begin{array}{l}\text { School Locational } \\
\text { Characteristics }\end{array}$ & $\begin{array}{c}\text { Average } \\
\text { Expected } \\
\text { Unit Costs }\end{array}$ & $\begin{array}{c}\text { Average } \\
\text { Actual } \\
\text { Unit Costs }\end{array}$ & $\begin{array}{c}\text { Average } \\
\text { Unit Costs } \\
\text { Variance }\end{array}$ & $\begin{array}{c}\text { Average } \\
\text { Unit Cost } \\
\text { Variance (\%) }\end{array}$ \\
\hline Rural & $65,788.00$ & $67,347.50$ & $1,559.50$ & 2.4 \\
\hline Urban & $77,758.00$ & $80,398.70$ & $2,640.70$ & 3.4 \\
\hline
\end{tabular}

Source: Ministry of Education Science and Technology, 2019.

The existing variance between the expected unit costs and the actual unit cost incurred as depicted in Table 1 perhaps indicate cost inefficiency. The percentages expressed the variance in costs. The average unit cost variance as indicated in table is $2.4 \%$ and $3.4 \%$ for rural and urban schools respectively. The cost efficiency levels vary according to the school characteristics including rural and urban.

The Kenya government, parents and organizations put in a considerable amount of financial resources to support education in public secondary schools. Cost efficiency is therefore critical to ensure that financial resources allocated to the education sector are fully utilized to realize maximum returns. It is expected that public secondary schools optimally allocate resources within the school setting, use the lowest unit cost and amount of resources possible to obtain the desired output. However, the background information shows that public secondary schools have not been able to operate efficiently in terms of costs. Misallocation of resources; unrealistic high unit costs and large amount of resources used making it impossible to save on costs have been the prevalent cost efficiency challenges in secondary schools. The factors influencing cost efficiency may vary in degrees from school to school. Records held in Bomet county education office show that most public secondary schools are cost inefficient in the way they operate (Bomet County Government., 2019). This is evidenced in the wide variation of the actual amount spent on educational items from the amount indicated in the budget. The high 
unit costs and the huge amount of resources used in education are common occurrences. Resources are also not optimally allocated to various educational needs within the school setting. The undesirable cost inefficiency levels in public secondary schools in Bomet County may perhaps be due to school characteristics such as school location.

\section{Research Objective}

To examine the influence of school location on cost efficiency in public secondary schools in Bomet County, Kenya.

\section{Empirical Literature}

Results of past researches examining school location in relation to cost efficiency are mixed and inconclusive. Using an online survey, a study conducted by Echazarra and Radinger (2019) to examine learning in rural schools in European Union countries found that rural school practices, such as teaching techniques, assessments, arrangement of space and time, and use of specific resources, could be informative in developing cost efficient learning environments. The study concluded that issues shaping cost efficiency in rural schools include teaching and learning environment, financial and material resources, school programmes, student specialized support and after school activities, adequate staffing of schools with trained teachers, teachers' preparation, learning and support, school leadership, school community relation, and communication and technology. Based on the findings, the study recommended that the government should prepare and build a supportive working environment for teachers in rural schools. The study also recommended use of technology to reduce cost and enhance efficiency. The results mimic Schafft (2016) whose findings indicate that cultivating school gardens, organizing school trips for benchmarking purposes and utilizing classroom time cushion rural schools from cost inefficiencies in USA. Supporting and connecting schools in rural locations with other schools may ultimately enhance cost efficiency.

In the sense of school location, the central question of whether actually allocating more money to schools results in higher cost efficiency is widely reviewed by diverse researchers. A study conducted by Gibbons et al. (2018) to examine the impact of school resources on student achievement in England found that school resources have an important role to play in improving educational attainment. The authors observed that allocating resources to school according to geographical location causes inefficiency in education. Regression results show that school expenditure differentials is associated with academic achievements differentials. This implies cost efficiency differentials across diverse school locations. The findings concur with Johnes et al. (2017) whose results underscored the importance of resources for realizing students' achievement in all schools. Schools need to minimize cost in using the educational resources in order to be efficient. 
Literature findings have shown that financial resources may affect cost efficiency. A study conducted by Ngo and Dustan (2019) to examine the effects of a massive, minimally targeted conditional cash transfer program in Mexico City's public high schools on efficiency as indicated by graduation rates, test scores, and school choice using a difference-in-differences approach found that this program had no appreciable effect on high school completion. The results show that high school exam scores are apparently unaffected by the cash transfer programme and effects on high school choices by eligible students are minimal. The study found no evidence for heterogeneous effects with respect to implicit or explicit cost of attendance, suggesting that liquidity constraints are not a key driver of high school dropout in this urban setting. These results highlight the challenges of using cash to improve academic outcomes in cities. In consistent to the results, Du Plessis and Mestry (2019) found that financial support issues impede acquisition of water, sanitation facilities, electricity and classrooms leading to serious implications of efficiency of schools in South Africa. Teaching and learning may not be effective in secondary schools if these basic requirements are not met.

Diverse challenges related to students, teachers, and facilities have continued to derail the guest for achieving higher cost efficiency levels in urban and rural secondary schools. Using descriptive qualitative approach to collect data at rural schools in Indonesia, Mudra (2018) found that the obstacles faced by the language teachers were around classroom management, learning materials or resources, teaching aids or media, teaching methods, learners' language skills, choice of language use, slow internet connectivity, learners' motivation, evaluation technique and parental support. The findings are in consonant with Wulan (2020) who identified prevalent challenges in rural schools such as mastery of vocabularies, students' motivation, parental support, the students' activeness; the teachers' familiarity of IT, mastery of teaching methods, teachers' training on pedagogy; and the facilities such as lack of representative building, computer and Liquid Crystal Display.

Studies focusing on examining cost efficiency are limited in South East Asia. However, a study conducted by Batool and Chaudry (2019) to determinant efficiency of public schools in Pakistan established that school location had insignificant positive impact on cost inefficiency scores of schools. Empirical findings based on regression analysis technique indicate that no efficiency differences exist between schools operating in rural areas compared to those operating in urban areas. The current study makes a departure from this research by employing correlational research design to make predictions of cost efficiency of public secondary schools based on school characteristics. The study findings reveal that inputs including students' enrolment, teachers' qualification, average experience of teachers and number of classrooms while output such as pass rate in terms of $A+, A, B$ and $C$ grades had impact on efficiency. The findings show that teachers' qualifications and experience had high significant positive impact on cost inefficiency of secondary schools. The results show that the insignificant influence of facilities on cost efficiency in secondary schools was due to low utilization of library and computer lab. The study also found that support facilities for extracurricular activities 
had no significant influence on cost efficiency in terms of students' scores as they involve only the mental and physical exercise of students. The findings concurred with Darma (2017) who established that school rural and urban location environmental factors such as road, electricity and water supply influenced cost efficiency among secondary schools in Nigeria.

Researches have documented the impacts of environmental factors on academic efficiency of rural and urban secondary schools. A study conducted by Darma (2017) to examine the effects of school location on academic performance using ex post facto design reveal that school location significantly influenced cost efficiency of secondary schools in Nigeria. The findings were attributed to the teachers' unwillingness to accept responsibilities in urban schools at the expense of rural schools. The study found that there was a difference in the effectiveness of teachers between urban and rural secondary schools. Results of the study also show that there was a difference in academic achievement between rural and urban secondary schools. The study concluded that the difference in efficiency between rural and urban secondary schools was due to the remoteness of some rural schools. The study recommended that government should establish schools in accessible areas where the communication network is good for easy supervision, inspection and monitoring. In addition, the study recommended seminars and workshops in order to enhance the effectiveness of teachers in urban and rural secondary schools. The results are in agreement with Ganiyu and Babalola (2016)whose findings showed that school location based on urban and rural area has more impact that is positive on mathematics students' performance.

Poor academic performance as an indicator of low cost efficiency is associated to rural secondary schools more than urban by diverse researchers. According to a study conducted by ISA (2014) to examine the effect of school location on mathematics students' performance in Nigeria using ex post facto design, cost efficiency in urban public secondary schools was significantly higher than the one for rural secondary schools. In contrast to this research, the current study used predictive correlational research design to investigate the influence of school location on cost efficiency of public secondary schools in Kenya. The study concluded that urban secondary school students performed better in academics than their counterparts in rural secondary schools. This signifies improved cost efficiency in urban secondary schools. The study recommended that the government should improve basic human and physical facilities in rural schools in order to enhance efficiency. The results of the study were in consensus with Ganiyu and Babalola (2016) whose findings indicate that pupils/students' ratio in rural secondary schools do not have some required learning materials. This could be the reason rural secondary schools are inefficient, thus fairness in the distribution of learning materials across rural and urban secondary schools is necessary.

Studies in the past view school location as an influencer of educational output. A study conducted by Adnan et al. (2018) to investigate the correlation between school location and students' performance in science in Nigeria established that students in urban schools performed better. This may be a sign of low cost efficiency in rural schools. 
The study attributed the poor performance in rural secondary schools to inadequate facilities and lack of interest among learners. The study used a descriptive survey research design, which largely differs in data analysis approach from current study that adopted predictive correlational research design to examine cost efficiency in public secondary schools. The study recommended that parents in rural areas should help their children to maintain interest in academics. The study further recommended that school systems should nature students in rural schools as well as their counterparts in urban schools through provision of adequate school facilities that would enhance efficiency. The results were in consonance with Ayub et al. (2017) whose study found that students in urban secondary schools performed better in mathematics than their counterparts in rural secondary schools in Malaysia. Based on the background information, there is need to know whether cost efficiency of secondary schools is influenced by the location of the school.

Researches show that rural schools face significant challenges that are peculiar to their environment. A study conducted by Du Plessis and Mestry (2019) identified a lack of parental interest in children's education, insufficient funding from the state, a lack of resources, under qualified teachers, and multi-grade teaching are some of the barriers to effective education among rural schools in South Africa. Their study to investigate the perceptions and experiences of teachers in rural schools using qualitative research within the interpretivist paradigm reveal that majority of the rural schools lacked water, sanitation facilities and electricity. The findings also show that classrooms were in deplorable conditions. These challenges can have serious consequences for efficient teaching and learning. The current study is peculiar in the sense that it used a mixture of qualitative and quantitative research approach to allow for a more complete and synergistic use of data in examining the influence of school location on cost efficiency in secondary schools in Kenya. The findings mimic Morgan et al. (2017) who found that inadequate access to water, sanitation and hygiene in schools affected negatively on educational outcome and hence cost efficiency among the rural schools in Kenya, Ethiopia, Mozambique, Rwanda, Uganda and Tanzania. Ensuring ready access to water and sanitation in rural secondary schools has tremendous potential to have a positive effect on educational achievements. The net effects on cost efficiency can also be positive.

One of the most researched areas in education is the effect of class size and pupil teacher ratio on educational outcome. Using descriptive survey research design, a study conducted by Waita et al. (2016) to examine the impact of student teacher ratio on students' academic scores in Kenya established that student teacher ratio significantly influenced cost efficiency in both rural and urban schools. The authors noted that schools were overenrolled, consequently raising student teacher ratio, resulting in inefficiency. The results suggest that there was a shortage of mathematics teachers in Kenyan rural schools, but the issue is not as pronounced in urban schools. The findings reveal that academic achievement was increasingly high in smaller class size in regular schools. The study concluded that the higher the student teacher ratio, the lower the academic scores. On the other hand, lowering the student teacher ratio to enhance academic performance 
may increase the cost of education by employing additional number of teachers. The study recommended that there is need for the government to employ more teachers to address the shortage occasioned by escalating enrolment in schools. The results coincide with Kyambi (2019) who concluded that rural and urban schools in Kenya had a higher pupil to teacher ratio, which had a significant negative effect on efficiency. Student teacher ratio is a critical variable in secondary schooling that requires treatment with caution by striking a balance between improving academic performance through small class sizes and increase costs.

\section{Conceptual Framework}

The conceptual framework presents a diagrammatic representation of independent variables, dependent variables and their indicators. The conceptual framework for the study is illustrated in Figure 1.

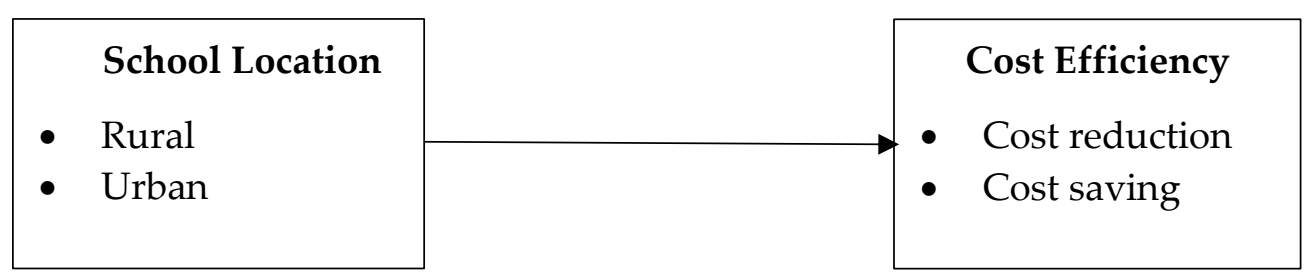

Figure 1: Conceptual Framework of School Location and Cost Efficiency

\section{Research Methodology}

The current study adopted post- positivism research philosophy owing to its flexibility in using various research instruments to examine cost efficiency of public secondary schools clearly and closely. Post- positivism world view considers both quantitative and qualitative methods to be valid in investigating a research phenomenon (Gathii et al., 2019). A post- positivist philosophical research approach advocates methodological pluralism based on the assumptions that the method to be applied in a particular study should be selected on the basis of research questions being addressed (Panhwar et al., 2017). Therefore, principal's questionnaire and the SCDE interview schedule were used in the present study to investigate the research phenomenon from various perspectives which helped to minimize the risk of biases and maximize reliability.

This study adopted predictive correlational research design in which the researcher used simple linear regression statistical processes to predict the value of the dependent variable based on the known value of the independent variable(Pituch \& Stevens, 2015). Predictive correlational design is used in those cases when there is an interest to identify predictive relationship between the predictor and the outcome/criterion variable (Mao et al., 2017).

The target population comprised all the two hundred and seventy (270) principals of public secondary schools and all the five (5) Sub-county Directors of Education (SCDE) 
in Bomet County. There were two hundred and seventy (270) public secondary schools and five (5) Sub Counties in Bomet County at the time of the study (Bomet County Government., 2019). Therefore, there were two hundred and seventy (270) principals and five (5) Sub County Directors of Education at the time of the study. The principals and SCDE were chosen to participate in the study because they are charged with the responsibility of effectively planning, implementing and managing the school budget in order to achieve the desired objectives of the school (Kamunge, 2016). The ability of the principals and the SCDEs having adequate and authoritative information on cost efficiency of public secondary schools influenced the validity of the research results. The target population of this study was considered as accessible population. Table 2 shows the accessible population by sub-county.

Table 2: Accessible Population by Sub-county

\begin{tabular}{|l|l|c|c|c|c|c|c|}
\hline \multicolumn{2}{|l|}{ Sub-county } & Sotik & Konoin & Bomet East & Bomet Central & Chepalungu & Total \\
\hline \multirow{2}{*}{ School location } & Rural & 71 & 33 & 25 & 29 & 52 & 210 \\
\cline { 2 - 8 } & Urban & 11 & 12 & 14 & 13 & 10 & 60 \\
\hline Principals & 82 & 45 & 39 & 42 & 62 & 270 \\
\hline SCDE & 1 & 1 & 1 & 1 & 1 & 5 \\
\hline
\end{tabular}

Source: Bomet County Education Office Data, 2019.

Table 2 shows that the number of principals in Sotik, Konoin, Bomet East, Bomet Central and Chepalungu sub- counties was eighty two (82), forty five (45), thirty nine (39), forty two (42) and sixty two (62) respectively totalling to two hundred and seventy (270). There was a sub- county director of education in each sub-county totalling to five (5) in the county.

A sample to represent the entire population in the study was chosen. According to Showkat and Parveen (2017) when accessible population is greater than $100(\mathrm{~N}>100)$, sampling is necessitated. Given that the study population comprised 270 principals, sampling was adopted. The sample size for the principals selected for the study was determined according to the formula by Krejcie and Morgan (1970) for a finite population as follows:

$$
S=\frac{X^{2} N P(1-P)}{d^{2}(N-1)+X^{2} P(1-P)}
$$

Where:

$S=$ Required Sample,

$X=Z$ - value (e.g. 1.96 for $95 \%$ confidence level),

$\mathrm{N}=$ Population Size,

$\mathrm{P}=$ Population proportion (expressed as decimal) (assumed to be $0.5(50 \%)$,

$\mathrm{d}=$ Degree of accuracy (5\%), expressed as a proportion (0.05); it is a margin of error. 
By inserting the required information into the formula, where $X=1.96, Z=270, P=$ 0.5 and $d=0.05$ gives:

$$
S=\frac{1.96^{2} \times 270 \times 0.5(1-0.5)}{0.05^{2}(270-1)+1.96^{2} \times 0.5(1-0.5)}
$$

$S=158.8021311777=159$ principals

This sample was increased by $10 \%$ to cater for possible non- responses (Guetterman et al., 2015). Therefore, the sample size increased to 175 principals. This represents the sample for the study and was obtained from the target population using proportionate stratified and simple random sampling methods. In addition, a census technique was used to select all the sub counties in the study area. Therefore, all the five (5) SCDE was sampled using purposive techniques in which a SCDE was selected to participate in the study. Table 3 shows the sampling matrix of the school location.

Table 3 : Sampling Matrix of School Location

\begin{tabular}{|l|c|c|c|}
\hline Sub- County & Rural & Urban & Total \\
\hline Sotik & 46 & 7 & 53 \\
\hline Konoin & 21 & 8 & 29 \\
\hline Bomet East & 16 & 9 & 25 \\
\hline Bomet Central & 19 & 8 & 27 \\
\hline Chepalungu & 35 & 6 & 41 \\
\hline Stratified Random Sample & 137 & 38 & 175 \\
\hline
\end{tabular}

Source: Ministry of Education Science and Technology, 2018.

From Table 3, rural and urban secondary schools constitute one hundred and thirty seven (137) and thirty eight respectively. The number selected from sotik, Konoin, Bomet East, Bomet Central and Chepalungu was fifty three (53), twenty nine (29), twenty five (25), twenty seven (27) and forty one (41) respectively. The total number of schools was one hundred and seventy five (175).

Two instruments, namely: Principal's Questionnaire and SCDEs' Interview Schedule were used to solicit data. Data was collected using a structured questionnaire from the principals of public secondary schools in order to address the research objectives of the study. The choice of a structured questionnaire was informed by the fact that it gathers information over a large sample and was more appropriate when addressing sensitive issues since it offers greater anonymity. The main objective of the principal's questionnaire in the current study was to obtain relevant data in the most reliable and valid manner. An interview schedule aimed at making it possible to obtain the data required to meet the specific objectives of the study was administered to SCDE. Respondents were probed using open ended questions. The guide solicited information covering school location and cost efficiency of public secondary schools. 


\section{Data Analysis}

Data analysis means breaking down a whole data into components (Li et al., 2016). Through assembly of the parts, one comes to understand the integrity of the whole. After data collection, the researcher conducted data cleaning which involved identifying incomplete and inaccurate responses. These were corrected to improve the quality of the responses. This study combined both qualitative and quantitative approaches in such a way as to maximize their strengths and minimize their limitations.

Table 4: Descriptive Statistics of Principals' Perception on School Location ( $\mathrm{n}=144)$

\begin{tabular}{|c|c|c|c|c|c|c|c|}
\hline & \multirow{2}{*}{$\begin{array}{l}1 \\
\mathbf{f} \\
\%\end{array}$} & \multirow{2}{*}{$\begin{array}{l}2 \\
\mathbf{f} \\
\%\end{array}$} & \multirow{2}{*}{$\begin{array}{l}3 \\
\mathbf{f} \\
\%\end{array}$} & \multirow{2}{*}{$\begin{array}{l}4 \\
\mathbf{f} \\
\%\end{array}$} & \multirow{2}{*}{$\begin{array}{l}5 \\
\mathbf{f} \\
\%\end{array}$} & \multicolumn{2}{|c|}{ Total } \\
\hline & & & & & & $\mathbf{M}$ & SD \\
\hline $\begin{array}{l}\text { The cost of water services provision is high } \\
\text { due to the school locale. }\end{array}$ & $\begin{array}{c}6 \\
4.2 \% \\
\end{array}$ & $\begin{array}{c}115 \\
79.9 \%\end{array}$ & $\begin{array}{c}7 \\
4.9 \% \\
\end{array}$ & $\begin{array}{c}5 \\
3.5 \% \\
\end{array}$ & $\begin{array}{c}11 \\
7.6 \% \\
\end{array}$ & 2.31 & .911 \\
\hline $\begin{array}{l}\text { The cost of electricity services provision is } \\
\text { largely high due to the location of the school. }\end{array}$ & $\begin{array}{c}7 \\
4.9 \%\end{array}$ & $\begin{array}{c}8 \\
5.6 \%\end{array}$ & $\begin{array}{c}12 \\
8.3 \%\end{array}$ & $\begin{array}{c}72 \\
50.0 \%\end{array}$ & $\begin{array}{c}45 \\
31.2 \%\end{array}$ & 3.97 & 1.031 \\
\hline $\begin{array}{l}\text { The cost of food supplies to school is high due } \\
\text { to the location of the school. }\end{array}$ & $\begin{array}{c}47 \\
32.6 \% \\
\end{array}$ & $\begin{array}{c}64 \\
44.4 \% \\
\end{array}$ & $\begin{array}{c}22 \\
15.3 \% \\
\end{array}$ & $\begin{array}{c}10 \\
6.9 \% \\
\end{array}$ & $\begin{array}{c}1 \\
0.7 \% \\
\end{array}$ & 1.99 & .908 \\
\hline $\begin{array}{l}\text { The administration cost of the school is high } \\
\text { due to the school location. }\end{array}$ & $\begin{array}{c}8 \\
5.6 \% \\
\end{array}$ & $\begin{array}{c}4 \\
2.8 \% \\
\end{array}$ & $\begin{array}{c}0 \\
0.0 \% \\
\end{array}$ & $\begin{array}{c}85 \\
59.0 \% \\
\end{array}$ & $\begin{array}{c}47 \\
32.6 \% \\
\end{array}$ & 4.10 & .966 \\
\hline $\begin{array}{l}\text { The costs incurred on extracurricular activities } \\
\text { in our school is high due to the school location. }\end{array}$ & $\begin{array}{c}1 \\
0.7 \%\end{array}$ & $\begin{array}{c}9 \\
6.2 \%\end{array}$ & $\begin{array}{c}18 \\
12.5 \%\end{array}$ & $\begin{array}{c}85 \\
59.0 \%\end{array}$ & $\begin{array}{c}31 \\
21.5 \%\end{array}$ & 3.94 & .809 \\
\hline $\begin{array}{l}\text { The cost of accessing workshop and seminars } \\
\text { by teachers is largely high due to the school } \\
\text { location. }\end{array}$ & $\begin{array}{c}4 \\
2.8 \%\end{array}$ & $\begin{array}{c}10 \\
6.9 \%\end{array}$ & $\begin{array}{c}18 \\
12.5 \%\end{array}$ & $\begin{array}{c}71 \\
49.3 \%\end{array}$ & $\begin{array}{c}41 \\
28.5 \%\end{array}$ & 3.94 & .970 \\
\hline $\begin{array}{l}\text { The costs of external support services (e.g., } \\
\text { motivational speakers) is high on the account } \\
\text { of school location. }\end{array}$ & $\begin{array}{c}0 \\
0.0 \%\end{array}$ & $\begin{array}{c}5 \\
3.5 \%\end{array}$ & $\begin{array}{c}30 \\
20.8 \%\end{array}$ & $\begin{array}{c}75 \\
52.1 \%\end{array}$ & $\begin{array}{c}34 \\
23.6 \%\end{array}$ & 3.96 & .765 \\
\hline $\begin{array}{l}\text { The transport costs for students on academic } \\
\text { trips in our school is due to the school location. }\end{array}$ & $\begin{array}{c}2 \\
1.4 \% \\
\end{array}$ & $\begin{array}{c}11 \\
7.6 \% \\
\end{array}$ & $\begin{array}{c}16 \\
11.1 \% \\
\end{array}$ & $\begin{array}{c}92 \\
63.9 \% \\
\end{array}$ & $\begin{array}{c}23 \\
16.0 \% \\
\end{array}$ & 3.85 & .828 \\
\hline $\begin{array}{l}\text { The school misses on cost saving aspects on } \\
\text { diverse operational costs due to school } \\
\text { location. }\end{array}$ & $\begin{array}{l}3 \\
2.1 \%\end{array}$ & $\begin{array}{c}18 \\
12.5 \%\end{array}$ & $\begin{array}{c}41 \\
28.5 \%\end{array}$ & $\begin{array}{c}63 \\
43.8 \%\end{array}$ & $\begin{array}{c}19 \\
13.2 \%\end{array}$ & 3.53 & .945 \\
\hline Average & & & & & & 3.51 & 0.90 \\
\hline
\end{tabular}

The objective of the study was to examine the influence of school location on cost efficiency in public secondary schools. This objective was examined using nine indicators. These indicators included the impact of school location to diverse expenses such as water services provision, electricity services provision, food supplies, administration cost, extracurricular activities, access to workshops and seminars, external support services, transportation costs, and missing on the cost saving opportunities. The study used Likert based questions with five-point Likert scale of 1= Very Small Extent (VSE), 2= Small Extent (SE), 3= Moderate Extent (ME), 4 = Large Extent (LE) and 5 = Very Large Extent (VLE). Furthermore, $\mathrm{f}=$ frequency, $\mathrm{M}=$ mean and $\mathrm{SD}=$ Standard Deviation. The results of 
the descriptive statistics due to the impact of school location on diverse cost areas were presented in Table 4.

The principals were asked on whether the school incurred a huge cost on the water services due to the school location. The principals indicated that it was only to a small extent $(\mathrm{M}=2.31, \mathrm{SD}=0.911)$. The study revealed that the school location influenced the water provision cost to a small extent. This can be attributable to the schools being largely in rural areas in which they would use the local water sources such as the river and utilize the rain water for their school consumption which would reduce the cost of availing water for various uses in the school. The study further examined on the impact of the cost of electricity due to school location. The respondents were in agreement to a large extent on the cost of electricity services provision being high on the account of school location $(\mathrm{M}=3.97, \mathrm{SD}=1.031)$. While the actual supply and installation of electricity to schools have been covered under last mile projects of Kenya Power on subsidized costs, the high costs of electricity supply can be realized in the costs attributable to wiring and maintenance within the schools. The schools being largely in rural areas may procure electricians from urban areas who might then need to factor in transport related costs in their billing.

On whether the cost of food supplies to the school was high due to the school location, the principals were in agreement to a small extent $(\mathrm{M}=1.99, \mathrm{SD}=0.908)$. The respondents indicated that there was low agreement on the food supplies of the school being high on the account of school location. This was attributable to most of the schools in Bomet County being in rural areas leading to the ease of procuring food from the local communities including parents which then lowers the costs associated with food procurement. On whether the administration costs of the schools were high due to the school location, the respondents were in agreement to a large extent $(M=4.10, S D=0.966)$ in respect to the metric. The high costs of administration of the rural schools could be attributed to the need of the school administrators to travel to the centralized and urban based offices of the education offices on diverse administration functions such as meetings. This leads to the increase in costs for those school administrators that need to travel from diverse locations to the urban centres for school related administrative functions.

The study further examined on whether the respondents incurred a huge cost on the extracurricular activities in respect to the school location. The study found that the respondents were in agreement that they incurred high expenses on extracurricular activities due to the school location $(\mathrm{M}=3.94, \mathrm{SD}=0.809)$. The high costs associated with the extra curriculum activities could be attributable to the need to travel to stadiums often situated in urban centres for the games. These travels have cost implications thus driving the cost aspects high in undertaking the activities. The study respondents further agreed to a large extent $(\mathrm{M}=3.94, \mathrm{SD}=0.970)$ that the cost of accessing workshops and seminars by teachers was high due to the school location. The results of this study can be attributable to the venues of the school workshops and seminars being in urban areas due to the availability of the requisite facilities. This has an impact on the cost implication. 
The study further found that the respondents indicated that the costs of external support services such as motivational speakers were high to a large extent $(M=3.96$, $\mathrm{SD}=0.765$ ) on the account of school location. The respondents were further asked on whether the transportation costs for the students on academic trips were high in the school due to the school location. The study found that the respondents agreed to a large extent $(\mathrm{M}=3.85, \mathrm{SD}=0.828)$ on the transportation costs for students on academic trips in the school being high due to the school location. The results of this study are consistent with that of Trihantoyo, Sholeh and Setyowati (2019) in a study based on the cost analysis of the community based transportation services which noted that the school location impacted on the school transportation costs. The schools that were remotely located would incur higher costs in contexts where the required services are often centralized in urban areas.

Finally, the study found that the respondents agreed to a large extent $(M=3.53$, $\mathrm{SD}=0.945$ ) that the school missed on cost saving aspects on diverse operational costs due to school location. The results of this study with respect to the school's location influencing missing of cost saving opportunities can be attributed to the schools within Bomet county being in rural set up. Schools in rural set up often miss on the cost saving opportunities. These results are similar to those of Kolbe, Baker, Atchison, Levin and Harris (2021) who noted that schools in rural areas often have higher operational costs associated with their geographical remoteness and sparsely populated schools which were then not able to benefit from economies of scale in their operations.

The respondents on average indicated that they thought the school location holistically influenced cost efficiency to a large extent $(\mathrm{M}=3.51, \mathrm{SD}=0.90)$. This can be attributable to high costs incurred on water and electricity services; administration; cocurricular activities; accessing workshop and seminars; external support services; and transport due to the location of the school in Bomet County. The standard deviation indicated that there was no consensus amongst the respondents due to a standard deviation of above 0.5 .

The study was further interested in the examination on whether the school location aspects had a statistically significant influence on the cost efficiency. The simple linear regression analysis was undertaken in order to examine on whether school location aspects had an influence on the cost efficiency aspects using the following hypothesis:

$\mathbf{H}_{\mathbf{0}}$ : There is no statistically significant influence of school location on cost efficiency of public secondary schools.

The results for the model summary of the school location were presented in Table 5.

Table 5: Model Summary of School Location

\begin{tabular}{|c|c|c|c|c|}
\hline Model & $\mathbf{R}$ & $\mathbf{R}$ Square & Adjusted R Square & Std. Error of the Estimate \\
\hline 1 & $.314^{\mathrm{a}}$ & .098 & .092 & .19968 \\
\hline
\end{tabular}


The results of the model summary indicated that the correlation coefficient (R) stood at 0.314 which indicated that there was a positive correlation between the school location and cost efficiency of public secondary schools in Bomet County. The coefficient of determination was further examined. The results revealed that the coefficient of determination (R Square) stood at 0.098 . A coefficient of determination of 0.098 indicated that $9.8 \%$ of the variance in the cost efficiency was a result of the school location aspects.

The study further examined on whether the regression model was good fit for data that is the model could predict the dependent variable. The results were presented in Table 6.

Table 6: ANOVAa of School Location

\begin{tabular}{|l|l|c|c|c|c|c|}
\hline \multicolumn{2}{|l|}{ Model } & Sum of Squares & df & Mean Square & F & Sig. \\
\hline \multirow{2}{*}{1} & .618 & 1 & .618 & \multirow{2}{*}{15.499} & \multirow{2}{*}{$.000^{\mathrm{b}}$} \\
\cline { 2 - 7 } & Regression & 5.662 & 142 & .040 & & \\
\cline { 2 - 6 } & Residual & 6.280 & 143 & & \\
\hline
\end{tabular}

The results of the study indicated that $\mathrm{F}_{0.05}(1,142)=15.499, \mathrm{p}$ value $=0.000(\mathrm{p}<0.05)$. According to Menard (2002), the p value of less than 0.05 (level of significance) indicates that the model has overall test of significance that is the model can predict the dependent variable. The regression model can predict the cost efficiency of public secondary schools in Bomet County.

The $\mathrm{t}$ tests and unstandardized regression coefficients were utilized for determining the statistical and practical significance of the relationship between school location and cost efficiency aspects. The analysis results were presented in Table 7.

Table 7: Coefficientsa of School Location

\begin{tabular}{|c|c|c|c|c|c|c|}
\hline \multirow{2}{*}{\multicolumn{2}{|c|}{ Model }} & \multicolumn{2}{|c|}{ Unstandardized Coefficients } & \multirow{2}{*}{$\begin{array}{c}\text { Standardized Coefficients } \\
\text { Beta } \\
\end{array}$} & \multirow{2}{*}{$\mathbf{t}$} & \multirow{2}{*}{ Sig. } \\
\hline & & B & Std. Error & & & \\
\hline \multirow{2}{*}{1} & (Constant) & 3.602 & .219 & & 16.449 & .000 \\
\hline & School Location & .219 & .056 & .314 & 3.937 & .000 \\
\hline
\end{tabular}

The study results revealed that $\mathrm{t} 0.025(142)=3.937, \mathrm{p}$ value $=0.000(\mathrm{p}<0.05)$. According to Weisberg (2005) achievement of the $p$ value of less than level of significance $(0.05)$ leads to the conclusion that the independent variable is a statistically significant predictor dependent variable. In the current study, school location was a statistically significant predictor of the cost efficiency in public secondary schools in Bomet County. The study further observed that a regression coefficient of 0.219 was achieved for the study. According to Darlington and Hayes (2017), a regression coefficient is used to determine the change in the dependent variable as a result of unit change in the independent variable. In this context, a unit change in school location aspects is associated with a 0.219 change in the cost efficiency of the public secondary schools in Bomet County, Kenya. 
Therefore, the regression equation was presented as Cost Efficiency $=3.602+0.219$ (School Location).

The interviewees also added their voice on the manner in which the school location impacted on the costs of running schools;

"Many rural schools face concerns that stem from demographic and economic state that is the lack of technology infrastructure, and the difficulty of hiring and retaining teachers. These pressures amount to low cost savings behaviours and high costs of education in rural areas." (Interviewee \#5)

"Schools in urban areas are usually larger, enjoy greater responsibility for resource allocation, less likely to experience staff shortage, have higher student-teacher ratio than schools in rural areas. They are therefore most likely to save costs than rural areas." (Interviewee \#4)

These results are similar to those of Kolbe et al., (2021) who noted that schools in rural areas often have higher operational costs associated with their geographical remoteness and sparsely populated schools which were then not able to benefit from economies of scale in their operations. Angundaru, Lubogoyi and Bagire (2016) in a study in Uganda alluded that the urban based schools are able to charge high fees compared to their rural based counterparts and hence achieve higher sources of revenue. Whalley and Barbour (2020) while discussing the context of rural schools within New Zealand noted that the rural schools within those regions incur huge costs in staff accessing training opportunities due to the distances involved.

\section{Conculsion of the Study}

The study also concluded on the presence of a statistically significant influence of school location on cost efficiency of public secondary schools in Bomet County. These results were attributed to higher operational costs associated with their geographical remoteness and sparsely populated schools, which were then not able to benefit from economies of scale in their operations.

\section{Recommendations of the Study}

The school location having been found to have an influence on the cost efficiency should be factored in budgeting and the requisite school resources mobilized. Rural schools that are cost disadvantaged should consider collaborating with neighbouring schools in procurement in order to create economies of scale.

\section{Conflict of Interest Statement}

The authors declare no conflicts of interests. 


\section{About the Authors}

Philip Kimutai arap Kirui is a Doctor of Philosophy Student at Egerton University while both Dr. David Kuria Wamukuru, and Dr. Fedha Flora are senior lecturers at the same university.

\section{References}

Adnan, A., Ismail, H., Umar, R. Z. R., Samuel, S., \& Hamid, M. (2018). Effect of Merging Lane Length on Motorcyclist's Head Check Behavior during Merging in Traffic: Urban Expressway. Transportation Research Board 97th Annual Meeting.

Agasisti, T., Falzetti, P., \& Soncin, M. (2016). Italian School Principals' Managerial Behaviors and Students' Test Scores: An Empirical Analysis (No. 709).

Angundaru, G., Lubogoyi, B., \& Bagire, V. (2016). Human Resource Practices and Teacher Engagement in the Rural Setting of Ugandan Schools. DBA Africa Management Review, 6(1), 44-56.

Ayub, A. F. M., Yunus, A. S. M., Mahmud, R., Salim, N. R., \& Sulaiman, T. (2017). Differences in Students' Mathematics Engagement Between Gender and Between Rural and Urban Schools. AIP Conference Proceedings, 1795(1), 20-25.

Barra, C., Lagravinese, R., \& Zotti, R. (2018). Does Econometric Methodology Matter to Rank Universities? An Analysis of Italian Higher Education System. Socio-Economic Planning Sciences, 62(1), 104-120.

Batool, T., \& Chaudry, M. O. (2019). Determinants of Efficiency of Public Schools in Pakistan A Case Study of Multan District. Journal of Economics and Sustainable Development, 10(9), 15-22.

Bomet County Government. (2019). Bomet County Education Office, 2019. https://bomet.go.ke/

Chepkwony, C. B., Ongeti, K., \& Wanyonyi, D. (2020). Teacher Qualifications and Experience in Devolved Management of Early Childhood Education to The County Government: A Comparison of Learner Performance Between Public and Private Schools in Kenya. European Journal of Education Studies, 7(7), 1-9.

Chirchir, P., Ngeno, V., \& Ngure, L. (2019). Influence of Income Generating Activities on Academic Performance in Public Secondary Schools in Ainamoi Sub-County, Kericho County, Kenya. International Journal of Scientific and Research Publications, 9(10), 582-58588.

Darlington, R. B., \& Hayes, A. F. (2017). Regression Analysis and Linear Models: Concepts, Application and Implementation. The Guilford Press.

Darma, K. R. (2017). The Influence of School Location and Teacher Effectiveness on Academic Achievement among Secondary School Students in Kano State. International Journal for Social Studies, 3(6), 54-65.

Du Plessis, P., \& Mestry, R. (2019). Teachers for Rural Schools-A Challenge for South Africa. South African Journal of Education, 39(1), 1-9. 
Echazarra, A., \& Radinger, T. (2019). Learning in Rural Schools: Insights from PISA, TALIS and the Literature (No. 196). OECD.

Ferraro, S., Agasisti, T., Porcelli, F., \& Soncin, M. (2021). Local Governments' Efficiency and Educational Results: Empirical Evidence from Italian Primary Schools. Applied Economics, 53(35), 1-23.

Flores, I. (2017). Modelling Efficiency in Education: How are European Countries Spending their Budgets and What Relation Between Money and Performance. Sociologia, Problemas e Práticas, 1(83), 157-170.

Ganiyu, M. A., \& Babalola, K. O. (2016). On Coefficient Determinants Involving Many Fekete-Szego-Type Parameters of Convex Functions. Acta Universitatis Apulensis, 47(1), 39-48.

Gathii, K. J., Wamukuru, D. K., Karanja, D., Muriithi, W., \& Maina, K. (2019). Research Methods, Data Analysis \& Defences (Building Competences In Education And Social Sciences Research) (1st ed.). Education and Social Sciences Research Association of Kenya (ESSRAK).

Gibbons, S., McNally, S., \& Viarengo, M. (2018). Does Additional Spending Help Urban Schools? An Evaluation Using Boundary Discontinuities. Journal of the European Economic Association, 16(5), 1618-1668.

Gralka, S., Wohlrabe, K., \& Bornmann, L. (2019). How to Measure Research Efficiency in Higher Education? Research Grants vs. Publication Output. Journal of Higher Education Policy and Management, 41(3), 322-341.

Guetterman, T. C., Fetters, M. D., \& Creswell, J. W. (2015). Integrating Quantitative and Qualitative Results in Health Science Mixed Methods Research Through Joint Displays. The Annals of Family Medicine, 13(6), 554-561.

Hanushek, E. A., \& Woessmann, L. (2012). Do Better Schools Lead to More Growth? Cognitive Skills, Economic Outcomes, and Causation. Journal of Economic Growth, 17(4), 267-321.

ISA, S. G. (2014). The Effect of School Location on Senior Secondary School Mathematics Students' Performance in Gaya Zonal Education Area of Kano State, Nigeria. IOSR Journal of Mathematics, 14(2), 48-50.

Johnes, J., Portela, M., \& Thanassoulis, E. (2017). Efficiency in Education. Journal of the Operational Research Society, 68(4), 331-338.

Kamunge, S. N. (2016). Survey of Budgeting Control Practices in Management of Secondary Schools: Case of Meru North Region in Kenya. [Unpublished Master of Business Administration Thesis].University of Nairobi.

Kitur, K., Choge, J., \& Tanui, E. (2020). Relationship between Principals' Transformational Leadership Style and Secondary School Students' Academic Performance in Kenya Certificate of Secondary Education in Bomet County, Kenya. Universal Journal of Educational Research, 8(2), 402-409.

Kolbe, T., Baker, B. D., Atchison, D., Levin, J., \& Harris, P. (2021). The Additional Cost of Operating Rural Schools: Evidence From Vermont. AERA Open, 7(1), 1-16.

Koriyow, H. A. (2017). The Impact of Subsidized Fees Programme on Students' Access to 
Quality Education in Public Secondary Schools in Wajir County, Kenya. [Unpublished Doctor of Education in Educational Planning Thesis].University of Nairobi.

Kosgei, A. C., Tanui, E., \& Rono, R. (2018). Influence Of Selected Leadership Styles Of Principals On Performance Of Public Secondary School In Narok South, Kenya. International Journal of Scientific and Education Research, 2(1), 34-60.

Krejcie, R. V, \& Morgan, D. W. (1970). Determining Sample Size for Research Activities. Educational and Psychological Measurement, 30(3), 607-610.

Kyambi, F. D. (2019). Effect of Pupil-Teacher Ratio on Curriculum Implementation Practices in Public Primary Schools in Mwingi North Sub-County, Kenya. [Unpublished Master of Education in Educational Administration Thesis].South Eastern Kenya University.

Li, E. S., Cheung, P., Reilly, M. O., Labossiere, J., Lee, F., Cowan, S., Bigam, D. L., \& Schmölzer, G. M. (2016). Exhaled CO 2 Parameters as a Tool to Assess VentilationPerfusion Mismatching during Neonatal Resuscitation in a Swine Model of Neonatal Asphyxia. PLOS ONE, 11(1), 1-11.

Mao, X., Li, Q., Xie, H., Lau, R. Y. K., Wang, Z., \& Paul Smolley, S. (2017). Least Squares Generative Adversarial Networks. Proceedings of the IEEE International Conference on Computer Vision, 2794-2802.

Menard, S. (2002). Applied Logistic Regression Analysis. SAGE Publications, Inc.

Messer, R. (2016). Teaching Variance Analysis for Cost Accounting: How to Achieve above Par Performance. In Advances in Accounting Education: Teaching and Curriculum Innovations. Emerald Group Publishing Limited.

Ministry of Education. (2018). Ministry of Education Science and Technology. https://www.education.go.ke/

Morgan, C., Bowling, M., Bartram, J., \& Kayser, G. L. (2017). Water, sanitation, and hygiene in schools: Status and implications of low coverage in Ethiopia, Kenya, Mozambique, Rwanda, Uganda, and Zambia. International Journal of Hygiene and Environmental Health, 220(6), 950-959.

Mudra, H. (2018). Pre-Service EFL Teachers' Experiences in Teaching Practicum in Rural Schools in Indonesia. Qualitative Report, 23(2), 1-9.

Ngo, D., \& Dustan, A. (2019). Closing the STEM Gender Gap: Choice, Access, and Policies in Mexico City High Schools. https://andrewdustan.com/pdf/stem_mexico_ngo_dustan.pdf

Panhwar, A. H., Ansari, S., \& Shah, A. A. (2017). Post-Positivism: An Effective Paradigm for Social and Educational Research. International Research Journal of Arts $\mathcal{E}$ Humanities (IRJAH), 45(45), 1-30.

Pituch, K. A., \& Stevens, J. P. (2015). Applied Multivariate Statistics for the Social Sciences: Analyses with SAS and IBM's SPSS. Routledge.

Schafft, K. A. (2016). Rural Education as Rural Development: Understanding the Rural School-Community Well-Being Linkage in a 21st-Century Policy Context. Peabody Journal of Education, 91(2), 137-154.

Showkat, N., \& Parveen, H. (2017). In-Depth Interview. Quadrant-I (e-Text). http://www.uop.edu.pk/ocontents/Lecture 4 indepth interview.pdf 
Trihantoyo, S., Sholeh, M., \& Setyowati, E. (2019). Cost Analysis in the Community-Based School Transportation Service. Advances in Social Science, Education and Humanities Research, 382(1), 122-126.

Waita, K. J., Mulei, K. O., Mueni, K. B., Mutune, M. J., \& Kalai, J. (2016). Pupil-Teacher Ratio and its Impact on Academic Performance in Public Primary Schools in Central Division, Machakos County, Kenya. European Journal of Education Studies, 1(1), 37-68.

Weisberg, S. (2005). Applied Linear Regression (3rd ed.). John Wiley \& Sons, Inc.

Whalley, R., \& Barbour, M. K. (2020). Collaboration and Virtual Learning in New Zealand Rural Primary Schools: A Review of the Literature. Turkish Online Journal of Distance Education, 21(2), 102-125.

Wulan Arum, R. (2020). Challenges of English Language Teaching in Rural Area: A Case Study at State Junour High School Number 3 Sungai Lilin ( A Rural Area in South Sumatera). [Unpublished Thesis].UIN Raden Fatah Palembang.

Xie \& Zhang. (2019). Emerging Two-Dimensional Monoelemental Materials (Xenes) for Biomedical Applications. Chemical Society Reviews, 48(1), 2891-2912. 
Philip Kimutai arap Kirui, David Kuria Wamukuru, Fedha Flora will be applied to their work. Under the terms of this license, no permission is required from the author(s) or publisher for members of the community to copy, distribute, transmit or adapt the article content, providing a proper, prominent and unambiguous attribution to the authors in a manner that makes clear that the materials are being reused under permission of a Creative Commons License. Views, opinions and conclusions expressed in this research article are views, opinions and conclusions of the author(s). Open Access Publishing Group and European Journal of Education Studies shall not be responsible or answerable for any loss, damage or liability caused in relation to/arising out of conflicts of interest, copyright violations and inappropriate or inaccurate use of any kind content related or integrated into the research work. All the published works are meeting the Open Access Publishing requirements and can be freely accessed, shared, modified, distributed and used in educational, commercial and non-commercial purposes under a Creative Commons Attribution 4.0 International License (CC BY 4.0). 